\title{
Investigation of Cold-Formed Steel Top-Hat Sections Under Bending
}

\author{
A. Uzzaman ${ }^{1}$, A.M. Wrzesien ${ }^{2}$, R. Hamilton ${ }^{1}$, J.B.P Lim ${ }^{2}$, and D. Nash ${ }^{1}$ \\ ${ }^{1}$ Department of Mechanical and Aerospace Engineering, The University of \\ Strathclyde, 75 Montrose Street, Glasgow G1 1XJ \\ ${ }^{2}$ SPACE, David Keir Building, Queen's University, Belfast, BT9 5AG, UK
}

Corresponding authors' information:

Dr Asraf Uzzaman

Post-doctoral KTP Associate

Department of Mechanical \& Aerospace Engineering

The University of Strathclyde

M331, James Weir Building, 75 Montrose Street, Glasgow, G1 1XJ,UK

e-mail: asraf.uzzaman@strath.ac.uk

phone number: +447877688785 . 


\begin{abstract}
In recent years, with the introduction of higher strength grades, cold-formed steel sections have become increasingly more slender. As a result, top-hat purlin sections have become an alternative to conventional zed purlins, particularly when smaller purlin spans (around $4 \mathrm{~m}$ ) are required. Such top-hat sections are torsionally stiffer than zed purlins, and have greater resistance against lateral-torsional buckling. Furthermore, they do not require anti-sag rods. However, when determining their strength, they are susceptible to buckling. In this paper, a combination of full-scale laboratory tests and finite element analyses are used to investigate the bending strength of such top-hat sections. Both upward and downward loading conditions are considered. In this paper, twenty-seven full-scale experimental tests on top-hat sections are described. The moment capacities obtained experimentally are compared against those predicted by the Eurocodes and non-linear elasto-plastic finite element analyses.
\end{abstract}

Keywords: Cold-formed steel, Purlins, Top-hat sections, Eurocode 3, Finite element analysis,

\title{
1 Introduction
}

Single storey steel portal frames buildings account for approximately $50 \%$ of all the constructional steel used in the UK, and $90 \%$ of all single storey buildings. Such buildings are constructed from a number of primary structural frames, which in turn support cold-formed steel purlins and side rails, which in turn support the cladding.

Although the purlins are secondary members (i.e. not the main structural loadbearing members), they still account for approximately $30 \%$ of the total cost of the building. For smaller buildings, having bay spacings (and therefore purlin spans) of 
around $4 \mathrm{~m}$, the specification of even the smallest zed purlins section available, can be shown to be over designed by as much as $30 \%$.

An alternative to conventional zed purlin for use in such smaller buildings is the tophat section. Such sections perform better than zed purlins against lateral torsional buckling. Furthermore, they are simple to install on site and, unlike zed purlins, do not require the installation of anti-sag rods.

The behaviour of hat shaped sections has received limited attention in the literature. Figure 1 (a) shows the hat shaped sections tested by Acharya and Schuster [1]. Pastor and Roure [2,3] tested hat shaped sections (see Figure 1(b)), considering the formation of the plastic hinge. A finite element analysis methodology was implemented to simulate the post collapse behaviour. Honfi [4] considered the design optimization of hat shaped sections (see Figure 1 (c)) by use a genetic algorithm taking into account the ultimate strength and serviceability restrictions of Eurocode.

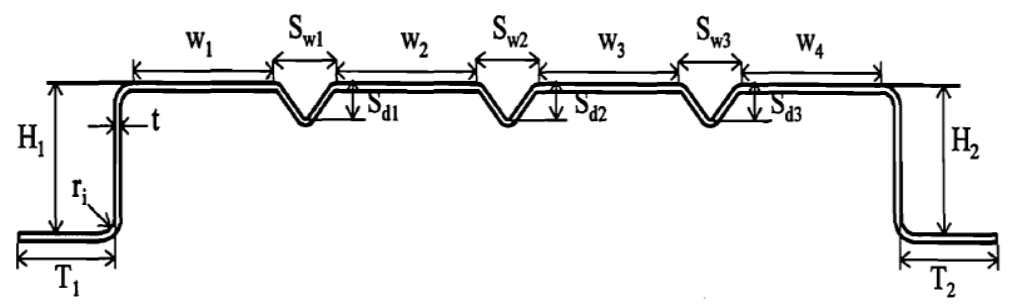

(a) Hat shaped section tested by Acharya and Schuster [1]
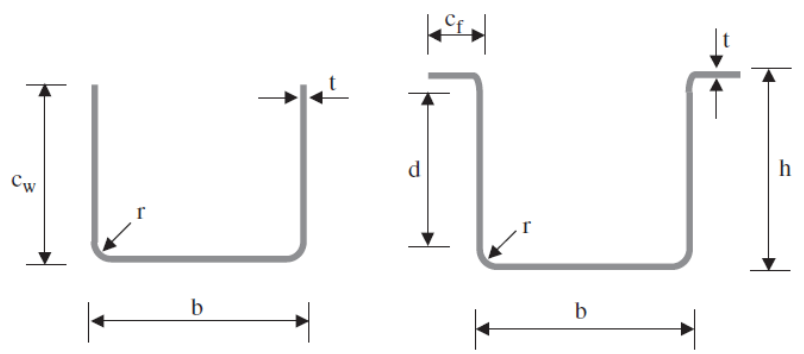

(b) Hat shaped section tested and finite element analysed by Pastor and Roure $[2,3]$

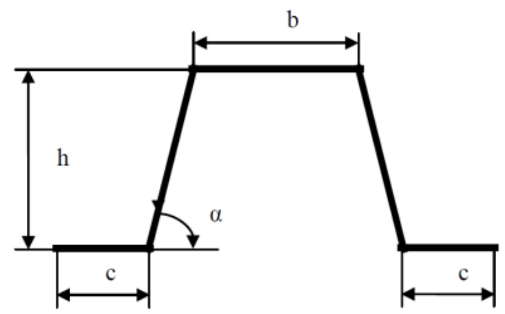

(c) Hat shaped section considered by Honfi [4]

Figure 1: Different hat shaped sections found in literature review 
In this paper, twenty-seven full-scale experimental tests on top-hat sections are described. The moment capacities obtained experimentally are compared against those predicted by the Eurocodes and non-linear elasto-plastic finite element analyses. Two loading directions are considered. Details of the four top-hat sections that will be considered in this paper are shown in Figure 2.

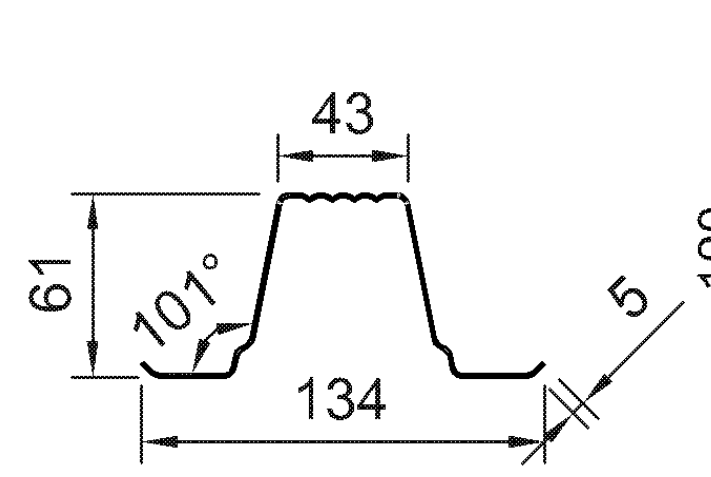

(a) Top-hat 61

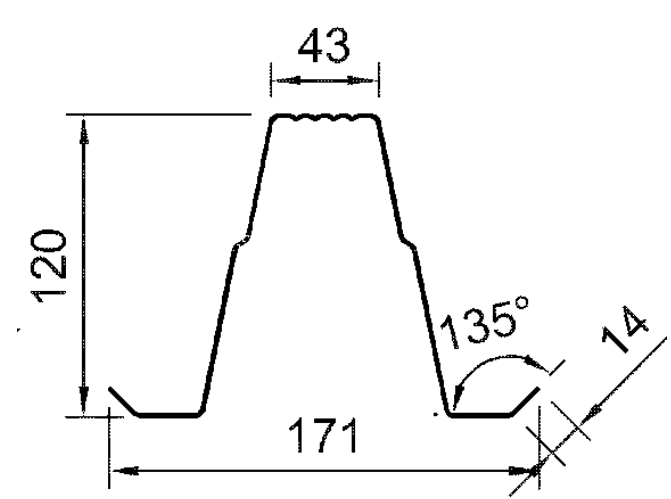

(c) Top-hat 120

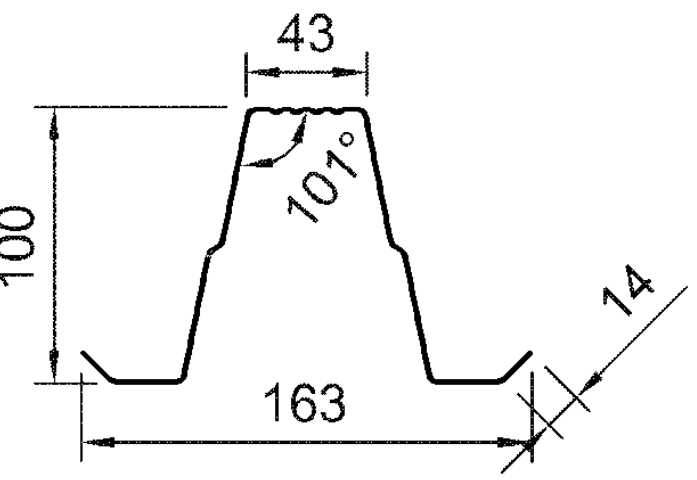

(b) Top-hat 100

Figure 2: Nominal dimensions of four types of top-hat section

\section{Experiment investigation}

\subsection{Test specimens}

Twenty-seven full-scale tests were conducted on four different geometries of top-hat sections under four point bending (see Figure 3), eleven tests in the under uplift and sixteen tests under gravity load. Full details of these full-scale tests can be found in Potter [5]. Two loading directions were considered: uplift (representing wind uplift load) and gravity load (representing vertical snow load). The nominal dimensions of 
the four types of top-hat sections are shown in Figure 2 (a, b, c and d). The nominal thickness of the top-hat sections was $1 \mathrm{~mm}$.

\subsection{Specimens labelling}

In Tables 2 and 3, the specimens were labelled such that the loading direction, the nominal overall height dimension of the specimen and number of test. For example, the labels "U-61-N1" and "G-61-N1" are explained as follows:

- The first notation defines loading direction of the test. " $U$ " represents loading under uplift condition and "G" represents loading under gravity condition.

- Second notation defines the nominal overall height dimension of the tophat section in millimetres $(61=61 \mathrm{~mm}, 100=100 \mathrm{~mm}, 120=120 \mathrm{~mm}$, $150=150 \mathrm{~mm})$.

- $\quad$ "N1" represents the number of repeat tests on same top-hat section.

\subsection{Material properties}

Tensile coupon tests were carried out to determine the material properties of the tophat specimens. The tensile coupons were taken from the centre of the web plate in the longitudinal direction of the untested specimens. The tensile coupons were prepared and tested according to the British Standard for Testing and Materials [6] for the tensile testing of metals using $12.5 \mathrm{~mm}$ wide coupons of a gauge length of 50 $\mathrm{mm}$. The coupons were tested in an MTS displacement controlled testing machine using friction grips. A calibrated extensometer of $50 \mathrm{~mm}$ gauge length was used to measure the longitudinal strain. Table 1 summarises the average yield and ultimate strengths of the top-hat sections, measured from three tensile coupons taken from top-hat sections, which includes the measured static $2 \%$ proof stress $\left(\sigma_{0.2}\right)$ and the static tensile strength $\left(\sigma_{u}\right)$.

\begin{tabular}{|c|c|c|}
\hline Specimen & $\begin{array}{c}\sigma_{0.2} \\
(\mathrm{MPa})\end{array}$ & $\begin{array}{c}\sigma_{\mathrm{u}} \\
(\mathrm{MPa})\end{array}$ \\
\hline $\mathrm{U}-61$ & 573 & 593 \\
\hline G-61 & 579 & 598 \\
\hline U-100 & 538 & 560 \\
\hline G-100 & 537 & 556 \\
\hline U-120 & 551 & 570 \\
\hline G-120 & 546 & 574 \\
\hline U-150 & 511 & 528 \\
\hline G-150 & 516 & 534 \\
\hline
\end{tabular}

Table 1: Mechanical properties obtained from tensile coupon tests 


\subsection{Test rig and procedure}

The four types of top-hat sections were tested under four point bending. Figure 3 (a) shows a schematic drawing of the test set up. Four point bending creates an area of uniform moment between the load points. At the ends of the sections, the top hats were bolted to pivoting support blocks. Load was applied through the timber blocks to prevent local crushing at the loading points. For the uplift loading direction the top-hat sections were turned bottom upwards (see Figure 3 (c)); similarly, for the gravity loading direction the top-hat sections were turned bottom downwards (see Figure 3 (b)); The loading jack was moved downwards in both tests.

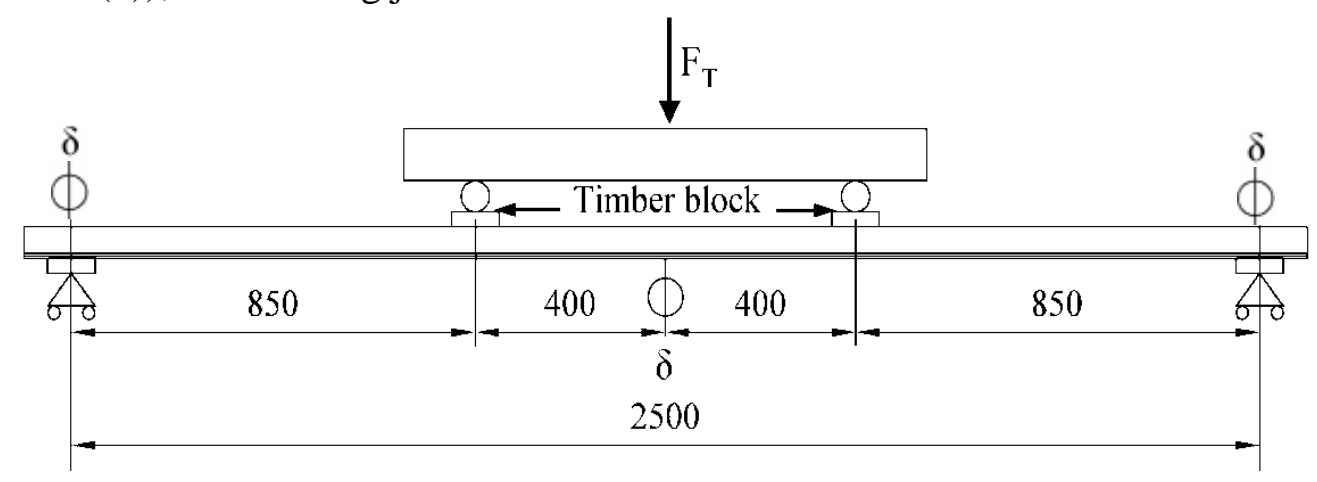

$\delta$ - displacement; $F_{T}$ - jacking force

(a) Schematic view of test set-up

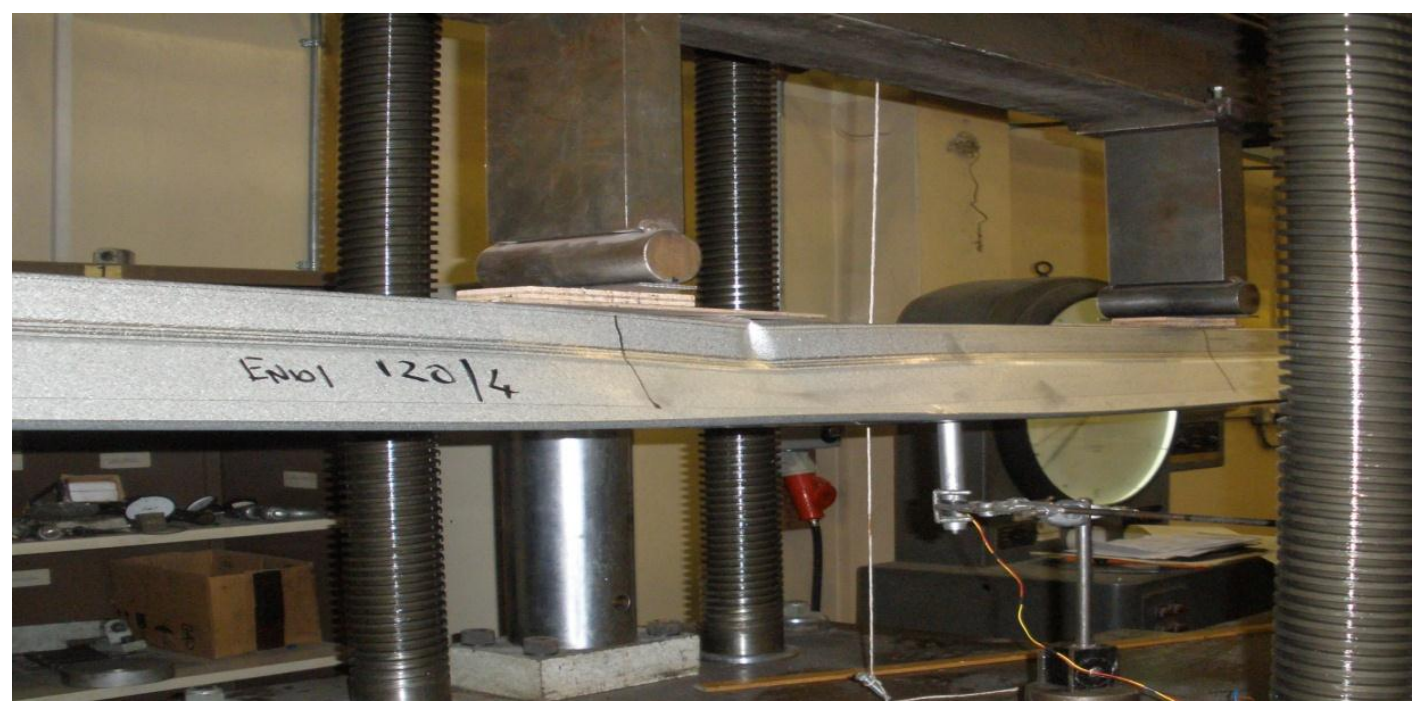

(b) Test photograph of gravity loading direction for G-120-N4 specimen 


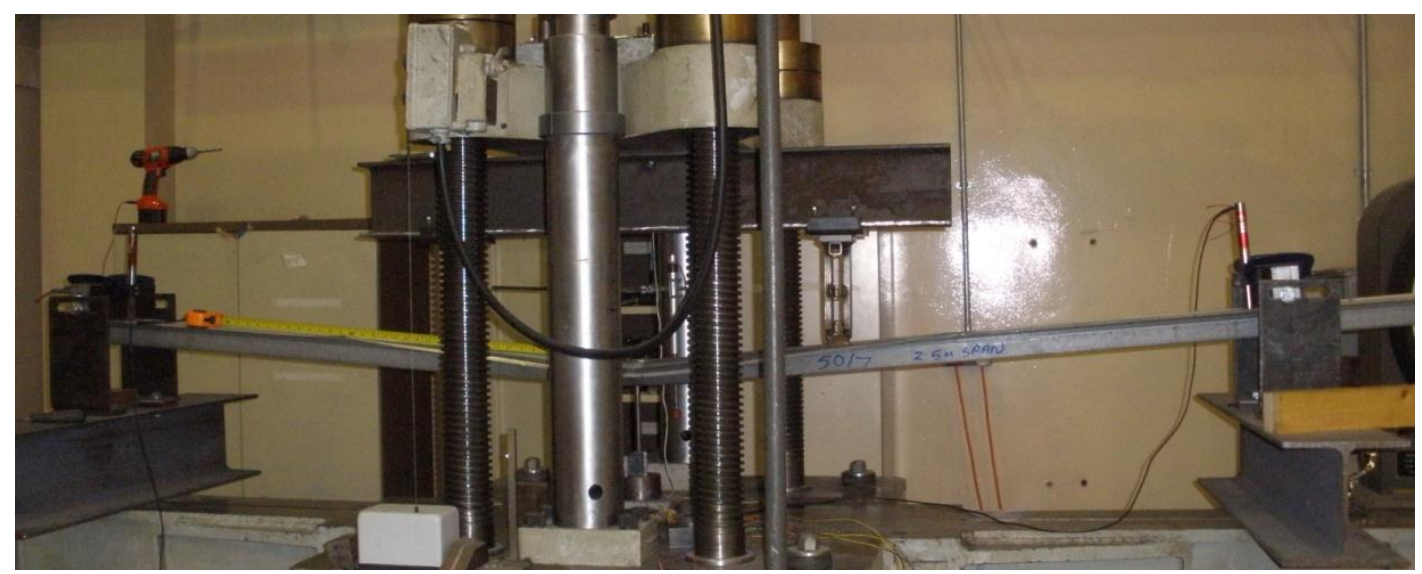

(c) Test photograph of uplift loading direction for U-61-N3 specimen

Figure 3: Details of the top-hat test arrangement under four point bending

Details of the test-rig supports are shown in Figure 4. As can be seen, elongated holes are used to represent a pinned connection. The test rig supports were designed such that rotation and horizontal translation could occur freely at the supports. In order to prevent axial force in the top-hat sections, elongated holes were provided through the introduction of a pin located in a kidney shaped hole. The bolts at the supports were also only finger-tightened. Before each test, load cycles to remove the slack from the top-hat sections were conducted. 


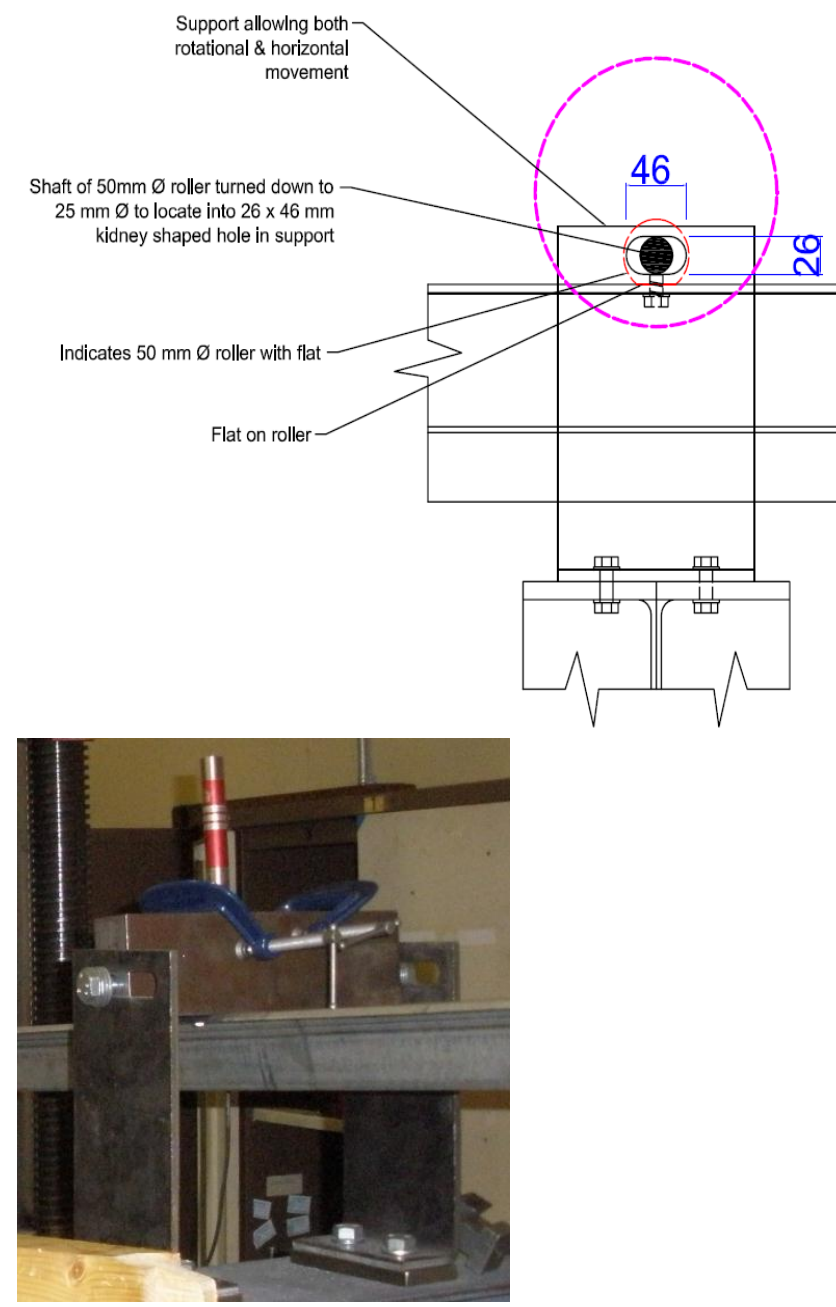

(a) Schematic view of test rig supports

(b) Photograph of test rig supports

Figure 4: Details of the test-rig supports

\subsection{Test Results}

The dimensions of the test specimens and the experimental ultimate loads $\left(\mathrm{P}_{\mathrm{EXP}}\right)$ are shown in Table 2 and Table 3 for the case of uplift and gravity loading direction, respectively. For each specimen, the ultimate moment capacities $\left(\mathrm{M}_{\mathrm{u}}^{\mathrm{EXP}}\right)$ are also calculated and are also shown in Tables 2 and Table 3.

\begin{tabular}{|c|c|c|c|c|c|c|}
\hline Specimen & Toe to toe & $\begin{array}{c}\text { Overall } \\
\text { height }\end{array}$ & $\begin{array}{c}\text { Thickness } \\
\text { excluding } \\
\text { galvanizing } \\
\text { coating }\end{array}$ & Test Span & $\begin{array}{c}\text { Load at } \\
\text { Failure } \\
\mathrm{P}_{\text {EXP }}\end{array}$ & $\begin{array}{c}\text { Moment at } \\
\text { Failure } \\
\mathrm{M}_{\mathrm{u}}^{\text {EXP }}\end{array}$ \\
\hline $\mathrm{mm}$ & $\mathrm{mm}$ & $\mathrm{mm}$ & $\mathrm{m}$ & $\mathrm{kN}$ & $\mathrm{kN}-\mathrm{m}$ \\
\hline $\mathrm{U}-61-\mathrm{N} 1$ & 143.45 & 57.44 & 0.99 & 2.50 & 3.39 & 1.44 \\
\hline
\end{tabular}




\begin{tabular}{|c|c|c|c|c|c|c|}
\hline U-61-N3 & 141.75 & 57.23 & 0.99 & 2.50 & 3.40 & 1.45 \\
\hline U-100-N1 & 163.50 & 99.00 & 0.96 & 2.75 & 3.71 & 1.81 \\
\hline U-100-N2 & 162.00 & 98.50 & 0.96 & 2.75 & 3.77 & 1.84 \\
\hline U-100-N3 & 167.50 & 98.50 & 0.96 & 2.75 & 3.75 & 1.83 \\
\hline U-120-N1 & 181.50 & 116.00 & 0.99 & 3.75 & 2.89 & 2.13 \\
\hline U-120-N2 & 183.00 & 116.00 & 0.97 & 3.75 & 2.80 & 2.07 \\
\hline U-150-N1 & 190.00 & 150.25 & 0.99 & 4.00 & 3.39 & 2.71 \\
\hline U-150-N2 & 192.00 & 149.50 & 0.98 & 4.00 & 3.30 & 2.64 \\
\hline U-150-N3 & 191.50 & 150.00 & 0.99 & 4.00 & 3.44 & 2.75 \\
\hline
\end{tabular}

Table 2: Specimen dimensions and experiment ultimate moment capacity under uplift loading direction

\begin{tabular}{|c|c|c|c|c|c|c|}
\hline Specimen & Toe to toe & $\begin{array}{c}\text { Overall } \\
\text { height }\end{array}$ & $\begin{array}{c}\text { Thickness } \\
\text { excluding } \\
\text { galvanizing } \\
\text { coating }\end{array}$ & Test Span & $\begin{array}{c}\text { Load at } \\
\text { Failure } \\
\mathrm{P}_{\text {EXP }}\end{array}$ & $\begin{array}{c}\text { Moment at } \\
\text { Failure } \\
\mathrm{M}_{\mathrm{u}}^{\text {EXP }}\end{array}$ \\
\hline & $\mathrm{mm}$ & $\mathrm{mm}$ & $\mathrm{mm}$ & $\mathrm{m}$ & $\mathrm{kN}$ & $\mathrm{kN}-\mathrm{m}$ \\
\hline G-61-N1 & 143.74 & 57.43 & 0.99 & 2.50 & 4.12 & 1.75 \\
\hline G-61-N2 & 144.42 & 56.96 & 0.98 & 2.50 & 4.09 & 1.74 \\
\hline G-61-N3 & 143.25 & 57.55 & 0.98 & 2.50 & 4.18 & 1.78 \\
\hline G-61-N4 & 144.28 & 57.13 & 0.98 & 2.50 & 4.19 & 1.78 \\
\hline G-100-N1 & 166.00 & 99.00 & 0.96 & 2.75 & 6.89 & 3.36 \\
\hline G-100-N2 & 168.00 & 98.55 & 0.97 & 2.75 & 6.86 & 3.34 \\
\hline G-100-N3 & 167.50 & 99.25 & 0.97 & 2.75 & 6.55 & 3.19 \\
\hline G-100-N4 & 163.50 & 98.75 & 0.99 & 2.50 & 7.79 & 3.31 \\
\hline G-120-N1 & 184.00 & 115.00 & 0.99 & 3.75 & 5.67 & 4.18 \\
\hline G-120-N2 & 189.00 & 114.75 & 0.98 & 3.75 & 5.68 & 4.19 \\
\hline G-120-N3 & 182.00 & 115.75 & 0.98 & 3.75 & 5.66 & 4.17 \\
\hline G-120-N4 & 181.50 & 115.25 & 0.98 & 3.75 & 5.61 & 4.14 \\
\hline G-150-N1 & 192.00 & 149.25 & 0.98 & 4.00 & 5.66 & 4.53 \\
\hline G-150-N2 & 190.00 & 149.50 & 0.98 & 4.00 & 5.79 & 4.63 \\
\hline G-150-N3 & 193.50 & 149.00 & 0.99 & 4.00 & 5.81 & 4.65 \\
\hline G-150-N4 & 194.00 & 149.25 & 0.98 & 3.50 & 6.89 & 4.65 \\
\hline
\end{tabular}

Table 3: Specimen dimensions and experimental ultimate moment capacity under gravity loading direction

\section{Eurocode 3 member resistances}

The moment capacity was calculated in accordance to EN 1993-1-3. The crosssection was simplified to straight line segments; every rounded corner was divided into two equal segments. Table 4 and Table 5 summarises the results of the design calculations.

\begin{tabular}{|c|c|c|c|c|c|c|}
\hline Specimen & $\begin{array}{c}\text { Thickness } \\
\text { excluding } \\
\text { galvanizing } \\
\text { coating }\end{array}$ & $\begin{array}{c}\text { Average } \\
\text { yield } \\
\text { strength }\end{array}$ & $\mathrm{M}_{\mathrm{u}}{ }^{\mathrm{EXP}}$ & $\mathrm{M}_{\text {gross,EC3 }}$ & $\mathrm{M}_{\text {eff,EC3 }}$ & $\mathrm{M}_{\mathrm{u}}^{\text {EXP }}$ \\
$/ \mathrm{M}_{\text {eff,EC3 }}$ \\
\hline $\mathrm{mm}$ & $\mathrm{N} / \mathrm{mm}^{2}$ & $\mathrm{kN}-\mathrm{m}$ & $\mathrm{kN}-\mathrm{m}$ & $\mathrm{kN}-\mathrm{m}$ & $\mathrm{kN}-\mathrm{m}$ \\
\hline $\mathrm{U}-61-\mathrm{N} 3$ & 0.99 & 573 & 1.45 & 2.26 & 1.38 & 1.05 \\
\hline
\end{tabular}




\begin{tabular}{|c|c|c|c|c|c|c|}
\hline U-120-N2 & 0.97 & 551 & 2.07 & 5.03 & 1.87 & 1.11 \\
\hline U-150-N3 & 0.99 & 511 & 2.75 & 5.32 & 2.76 & 1.00 \\
\hline Mean & & & & & & 0.99 \\
\hline COV & & & & & & 0.11 \\
\hline
\end{tabular}

Table 4: Moment capacity obtained from analytical analysis under uplift loading direction

\begin{tabular}{|c|c|c|c|c|c|c|}
\hline Specimen & $\begin{array}{c}\text { Thickness } \\
\text { excluding } \\
\text { galvanizing } \\
\text { coating }\end{array}$ & $\begin{array}{c}\text { Average } \\
\text { yield } \\
\text { strength }\end{array}$ & $\mathrm{M}_{\mathrm{u}}^{\mathrm{EXP}}$ & $\mathrm{M}_{\text {gross,EC3 }}$ & $\mathrm{M}_{\text {eff,EC3 }}$ & $\mathrm{M}_{\mathrm{u}}{ }^{\mathrm{EXP}}$ \\
\hline & $\mathrm{mm}$ & $\mathrm{N} / \mathrm{mm}^{2}$ & $\mathrm{kN}-\mathrm{m}$ & $\mathrm{kN}-\mathrm{m}$ & $\mathrm{kN}-\mathrm{m}$ & $\mathrm{kN}-\mathrm{m}$ \\
\hline G-61-N1 & 0.99 & 579 & 2.26 & 2.26 & 1.75 & 0.77 \\
\hline G-100-N2 & 0.97 & 537 & 3.62 & 3.90 & 3.34 & 0.92 \\
\hline G-120-N2 & 0.99 & 546 & 4.61 & 5.03 & 4.19 & 0.91 \\
\hline G-150-N2 & 0.98 & 516 & 5.08 & 5.32 & 4.63 & 0.91 \\
\hline Mean & & & & & & 0.88 \\
\hline COV & & & & & & 0.07 \\
\hline
\end{tabular}

Table 5: Moment capacity obtained from analytical analysis under gravity loading direction

\section{Numerical Investigation}

\subsection{General}

The non-linear elasto-plastic general purpose finite element program ANSYS (2011) was used to simulate the top-hat sections subjected to pure bending. In the finite element model, the measured cross-section dimensions and the material properties obtained from the tests were used. Imperfections of the top-hat section were not considered in the model. The model was based on the centreline dimensions of the cross-sections. Specific modeling issues are described in the following sections.

\subsection{Geometry and material properties}

Owing to symmetry about the vertical plane, only one-half of the test set-up was modelled (see Figure 5). The value of Young's modulus was $203 \mathrm{kN} / \mathrm{mm}^{2}$ and Poisson's ratio was 0.3 . The material non-linearity was incorporated in the finite element model by specifying 'true' values of stresses and strains. The plasticity of the material was determined by a mathematical model, known as the incremental plasticity model; the true stress and plastic true strain were as per the specified method in the ANSYS manual [8]. 


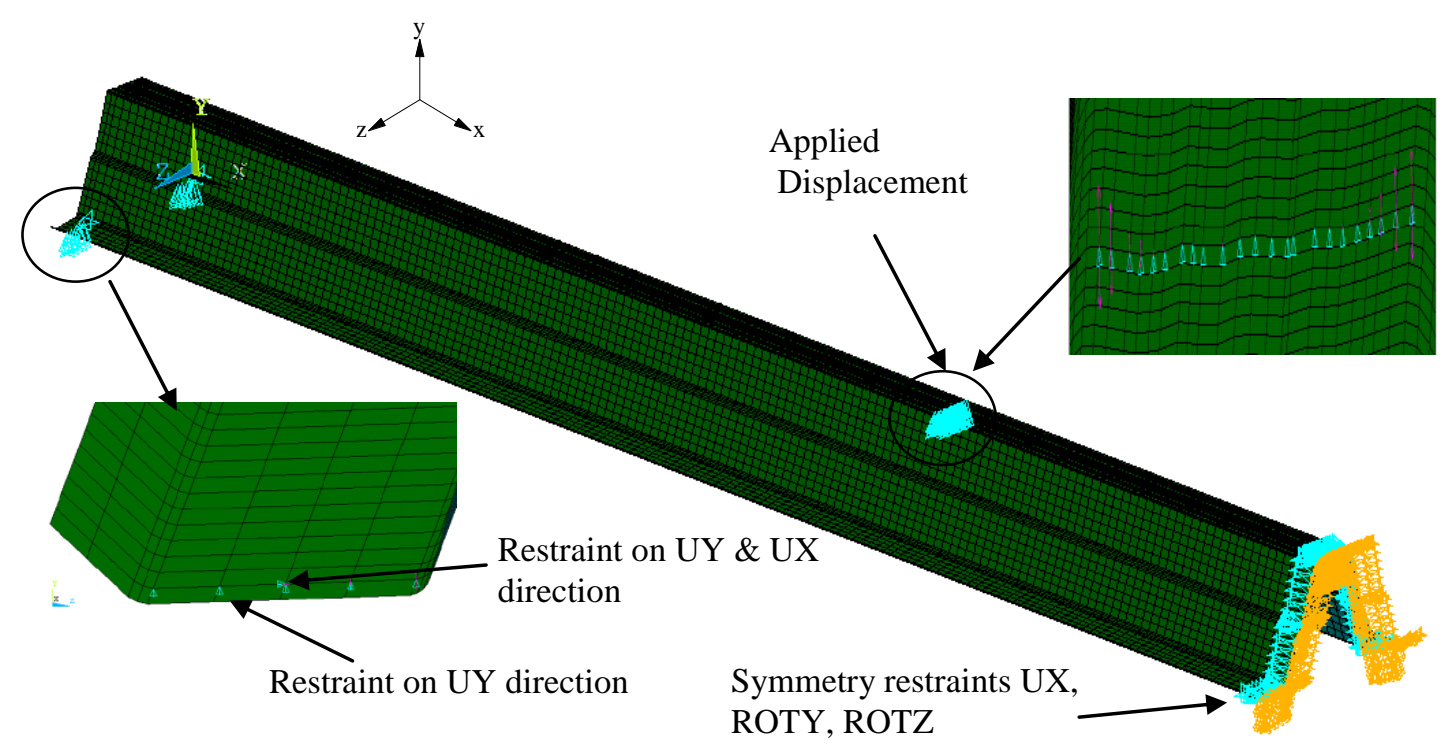

Figure 5: Details of finite element idealization

\subsection{Element type and mesh sensitivity}

Figure 5 shows details of a typical finite element mesh of the top-hat section. The effect of different element sizes in the cross-section of the top-hat section was investigated to provide both accurate results and reduced computation time. The finite element mesh sizes ranged was $10 \times 10 \mathrm{~mm}$ (length by width. Three elements were used around the inside corner radius that forms the bend. Along the length of the top-hat sections, the number of elements was chosen so that the aspect ratio of the elements was as close to one as possible. Mesh sensitivity analyses were performed to verify the number of elements. The top-hat sections were modeled using the 4-noded shell element SHELL181.

\subsection{Loading and boundary conditions}

The nodes of the cold-formed top-hat steel section were restrained to represent the vertical symmetry condition. The vertical load applied to the top-hat sections in the laboratory tests was modeled using displacement control; an imposed displacement is applied to all nodes in a line strip (line region) of the upper top-hat section where the vertical load (Y direction) is applied. Supports were modelled through in line regions. The nodes in line regions were restrained Y directions. The nodes where restrained in $\mathrm{Z}$ direction where the bottom flanges of the top-hat section were connected to the support plates.

\subsection{Verification of finite element model}


In order to validate the finite element model, the experimental moment capacity was compared against the ultimate moment predicted by the finite element analysis. The main objective of this comparison was to verify and check the accuracy of the finite element model. A comparison of the test results $\left(\mathrm{M}_{\mathrm{u}}^{\mathrm{EXP}}\right)$ with the numerical results $\left(\mathrm{M}_{\mathrm{u}}{ }^{\mathrm{FEA}}\right)$ of the top-hat ultimate moment is shown in Table 6 and Table 7 for the uplift and gravity loading condition, respectively.

Moment-deflection curves comparing the experimental results and the finite element results are shown in Figures 6 to 9. It can be seen that good agreement in stiffness has been achieved between both results for all specimens. However, as expected, the finite element model over predicts the strength of the top-hat sections. Considering one-half test set up, the ultimate failure mode observed from the tests has been also verified by finite element model for both loading direction, as shown in Figure 10 and Figure 11.

\begin{tabular}{|c|c|c|c|}
\hline Specimen & $\mathrm{M}_{\mathrm{u}}^{\text {EXP }}$ & $\mathrm{M}_{\mathrm{u}}^{\text {FEA }}$ & $\begin{array}{c}\mathrm{M}_{\mathrm{u}}^{\text {EXP }} \\
\mathrm{i}_{\mathrm{u}}^{\text {EFA }}\end{array}$ \\
\hline & $\mathrm{kN}-\mathrm{m}$ & $\mathrm{kN}-\mathrm{m}$ & \\
\hline $\mathrm{U}-61-\mathrm{N} 1$ & 1.44 & 1.44 & 1.00 \\
\hline $\mathrm{U}-61-\mathrm{N} 2$ & 1.45 & 1.43 & 1.02 \\
\hline U-61-N3 & 1.45 & 1.43 & 1.01 \\
\hline Mean & & & 1.01 \\
\hline COV & & & 0.01 \\
\hline
\end{tabular}

(a) Top-hat 61

\begin{tabular}{|c|c|c|c|}
\hline Specimen & $\mathrm{M}_{\mathrm{u}}^{\text {EXP }}$ & $\mathrm{M}_{\mathrm{u}}^{\text {FEA }}$ & $\begin{array}{c}\mathrm{M}_{\mathrm{u}}^{\text {EXP }} \\
\mathrm{M}_{\mathrm{u}}^{\text {FEA }}\end{array}$ \\
\hline & $\mathrm{kN}-\mathrm{m}$ & $\mathrm{kN}-\mathrm{m}$ & \\
\hline $\mathrm{U}-100-\mathrm{N} 1$ & 1.81 & 2.15 & 0.84 \\
\hline $\mathrm{U}-100-\mathrm{N} 2$ & 1.84 & 2.17 & 0.85 \\
\hline U-100-N3 & 1.83 & 2.15 & 0.85 \\
\hline Mean & & & 0.85 \\
\hline COV & & & 0.005 \\
\hline
\end{tabular}

(b) Top-hat 100

\begin{tabular}{|c|c|c|c|}
\hline Specimen & $\mathrm{M}_{\mathrm{u}}^{\text {EXP }}$ & $\mathrm{M}_{\mathrm{u}}^{\text {FEA }}$ & $\begin{array}{c}\mathrm{M}_{\mathrm{u}}^{\text {EXP }} \\
/ \mathrm{M}_{\mathrm{u}}^{\text {FEA }}\end{array}$ \\
\hline & $\mathrm{kN}-\mathrm{m}$ & $\mathrm{kN}-\mathrm{m}$ & \\
\hline $\mathrm{U}-120-\mathrm{N} 1$ & 2.13 & 2.68 & 0.80 \\
\hline $\mathrm{U}-120-\mathrm{N} 2$ & 2.07 & 2.60 & 0.80 \\
\hline Mean & & & 0.08 \\
\hline COV & & & 0.001 \\
\hline
\end{tabular}

(c) Top-hat 120 


\begin{tabular}{|c|c|c|c|}
\hline Specimen & $\mathrm{M}_{\mathrm{u}}{ }^{\text {EXP }}$ & $\mathrm{M}_{\mathrm{u}}^{\text {FEA }}$ & $\begin{array}{c}\mathrm{M}_{\mathrm{u}}^{\text {EXP }} \\
\mathrm{M}_{\mathrm{u}}{ }^{\text {FEA }}\end{array}$ \\
\hline & $\mathrm{kN}-\mathrm{m}$ & $\mathrm{kN}-\mathrm{m}$ & \\
\hline U-150-N1 & 2.71 & 3.13 & 0.87 \\
\hline U-150-N2 & 2.64 & 2.97 & 0.89 \\
\hline U-150-N3 & 2.75 & 3.06 & 0.90 \\
\hline Mean & & & 0.88 \\
\hline COV & & & 0.01 \\
\hline
\end{tabular}

(d) Top-hat 150

Table 6: Comparison of experimental test results and finite element analysis results under uplift loading direction

\begin{tabular}{|c|c|c|c|}
\hline Specimen & $\mathrm{M}_{\mathrm{u}}^{\text {EXP }}$ & $\mathrm{M}_{\mathrm{u}}^{\text {FEA }}$ & $\begin{array}{c}\mathrm{M}_{\mathrm{u}}^{\text {EXP }} \\
/ \mathrm{M}_{\mathrm{u}}^{\text {FEA }}\end{array}$ \\
\hline & $\mathrm{kN}-\mathrm{m}$ & $\mathrm{kN}-\mathrm{m}$ & 0.89 \\
\hline G-61-N1 & 1.75 & 1.96 & 0.91 \\
\hline G-61-N2 & 1.74 & 1.90 & 0.92 \\
\hline G-61-N3 & 1.78 & 1.93 & 0.93 \\
\hline G-61-N4 & 1.78 & 1.91 & 0.91 \\
\hline Mean & & & 0.02 \\
\hline COV & & & \\
\hline
\end{tabular}

(a) Top-hat 61

\begin{tabular}{|c|c|c|c|}
\hline Specimen & $\mathrm{M}_{\mathrm{u}}^{\text {EXP }}$ & $\mathrm{M}_{\mathrm{u}}^{\text {FEA }}$ & $\begin{array}{c}\mathrm{M}_{\mathrm{u}}^{\text {EXP }} \\
\mathrm{M}_{\mathrm{u}}^{\text {FEA }}\end{array}$ \\
\hline & $\mathrm{kN}-\mathrm{m}$ & $\mathrm{kN}-\mathrm{m}$ & \\
\hline $\mathrm{G}-100-\mathrm{N} 1$ & 3.36 & 3.23 & 1.04 \\
\hline G-100-N2 & 3.34 & 3.76 & 0.89 \\
\hline G-100-N3 & 3.19 & 3.24 & 0.98 \\
\hline Mean & & & 0.97 \\
\hline COV & & & 0.06 \\
\hline
\end{tabular}

(b) Top-hat 100

\begin{tabular}{|c|c|c|c|}
\hline Specimen & $\mathrm{M}_{\mathrm{u}}^{\text {EXP }}$ & $\mathrm{M}_{\mathrm{u}}^{\text {FEA }}$ & $\begin{array}{c}\mathrm{M}_{\mathrm{u}}^{\text {EXP }} \\
/ \mathrm{M}_{\mathrm{u}}^{\text {FEA }}\end{array}$ \\
\hline & $\mathrm{kN}-\mathrm{m}$ & $\mathrm{kN}-\mathrm{m}$ & \\
\hline $\mathrm{G}-120-\mathrm{N} 1$ & 4.18 & 4.95 & 0.84 \\
\hline $\mathrm{G}-120-\mathrm{N} 2$ & 4.19 & 5.00 & 0.84 \\
\hline $\mathrm{G}-120-\mathrm{N} 3$ & 4.17 & 5.05 & 0.83 \\
\hline G-120-N4 & 4.14 & 4.67 & 0.89 \\
\hline Mean & & & 0.85 \\
\hline COV & & & 0.01 \\
\hline
\end{tabular}

(c) Top-hat 120 


\begin{tabular}{|c|c|c|c|}
\hline Specimen & $\mathrm{M}_{\mathrm{u}}{ }^{\text {EXP }}$ & $\mathrm{M}_{\mathrm{u}}^{\text {FEA }}$ & $\begin{array}{c}\mathrm{M}_{\mathrm{u}}^{\text {EXP }} \\
\mathrm{M}_{\mathrm{u}}{ }^{\text {FEA }}\end{array}$ \\
\hline & $\mathrm{kN}-\mathrm{m}$ & $\mathrm{kN}-\mathrm{m}$ & \\
\hline $\mathrm{G}-150-\mathrm{N} 1$ & 4.53 & 5.24 & 0.86 \\
\hline $\mathrm{G}-150-\mathrm{N} 2$ & 4.63 & 4.91 & 0.94 \\
\hline G-150-N3 & 4.65 & 4.93 & 0.94 \\
\hline Mean & & & 0.92 \\
\hline COV & & & 0.04 \\
\hline
\end{tabular}

(d) Top-hat 150

Table 7: Comparison of experimental test results and finite element analysis under gravity loading direction

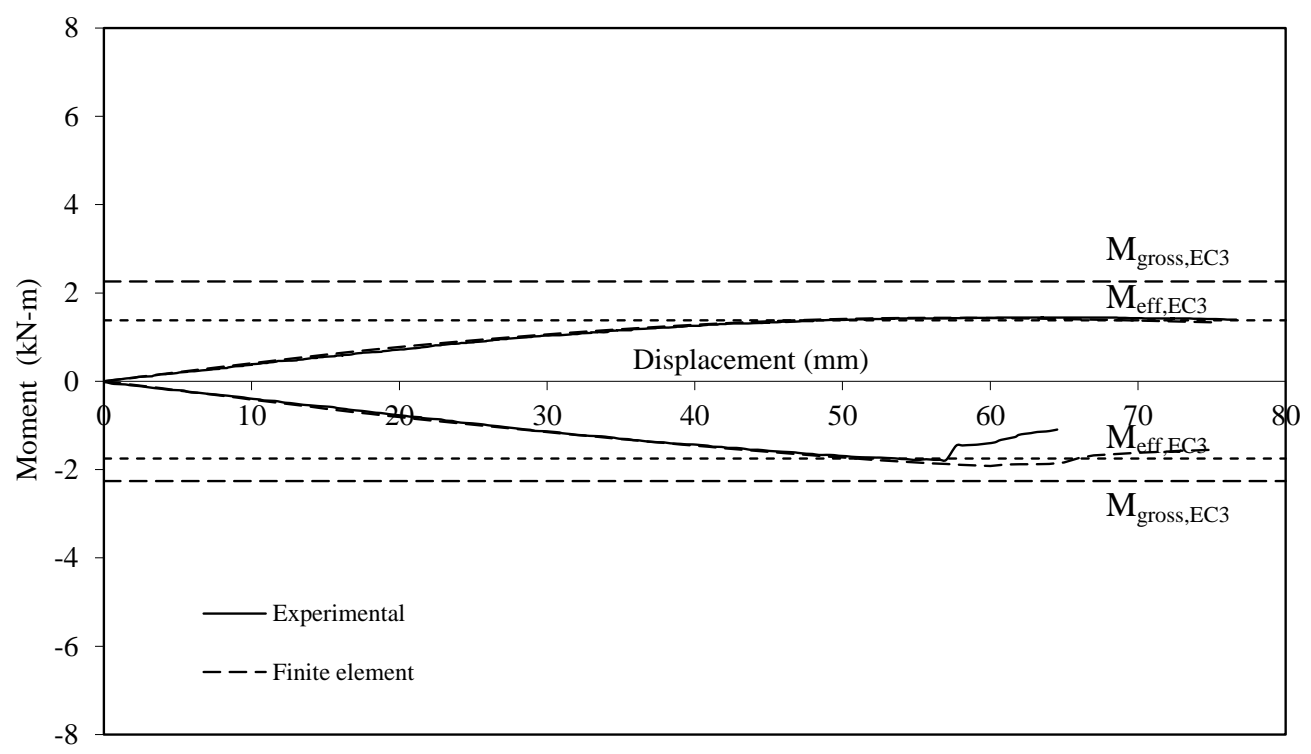

Figure 6: Variation of bending moment against central deflection for U-61-N3 and G-61-N1 specimens 


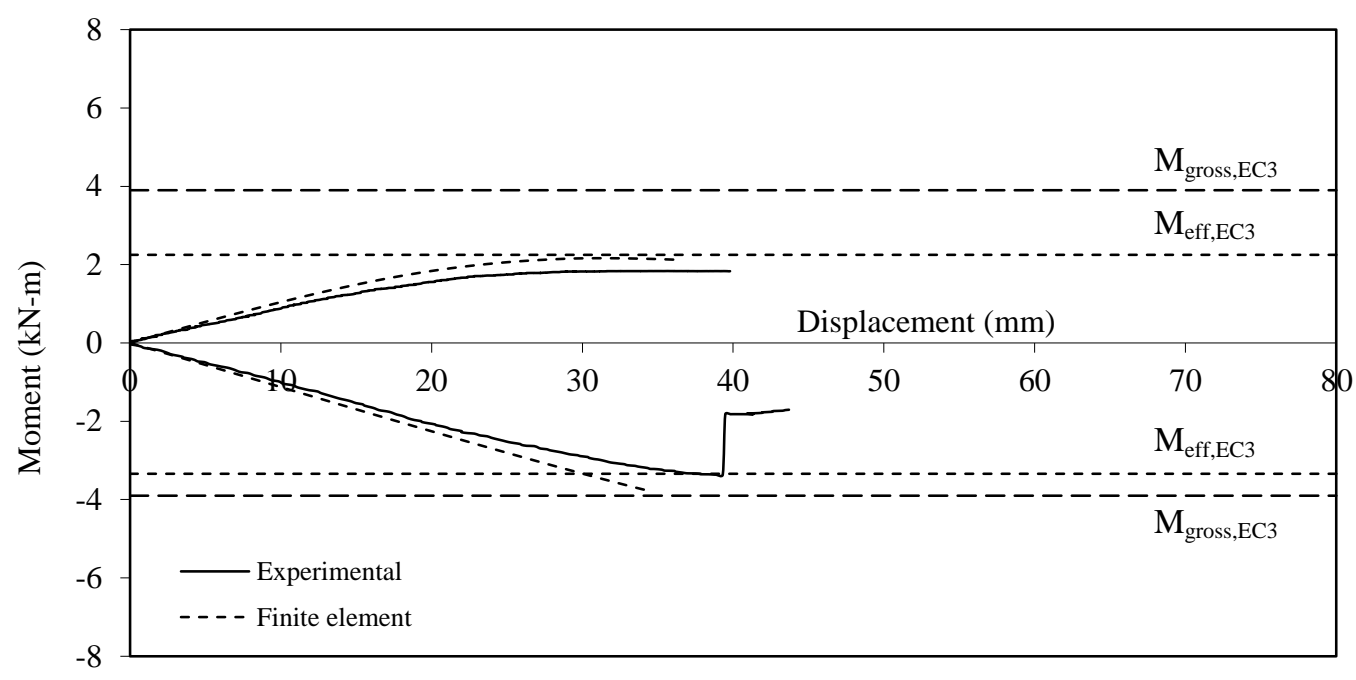

Figure 7: Variation of bending moment against central deflection for U-100-N3 and G-100-N2 specimens

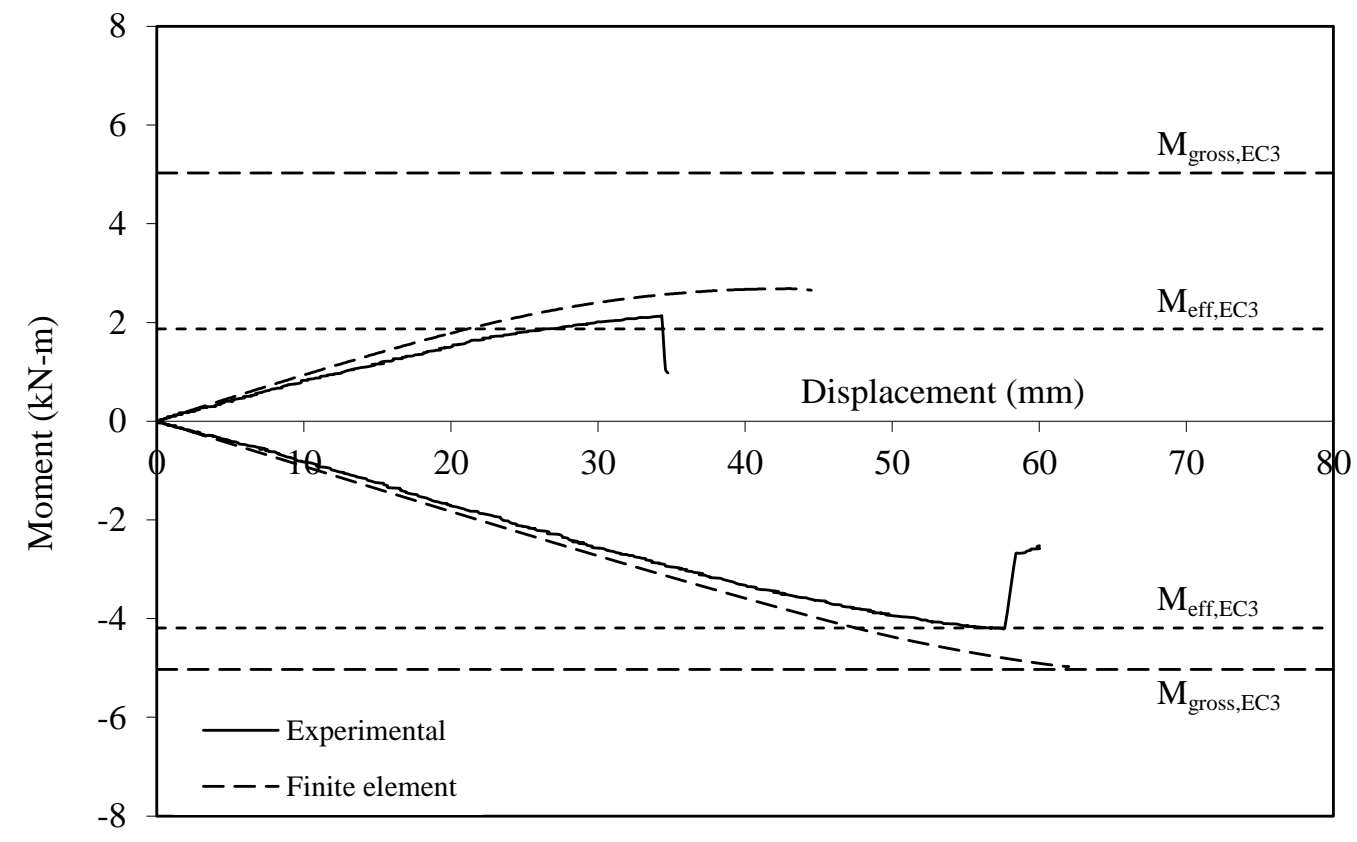

Figure 8: Variation of bending moment against central deflection for U-120-N2 and G-120-N2 specimens 


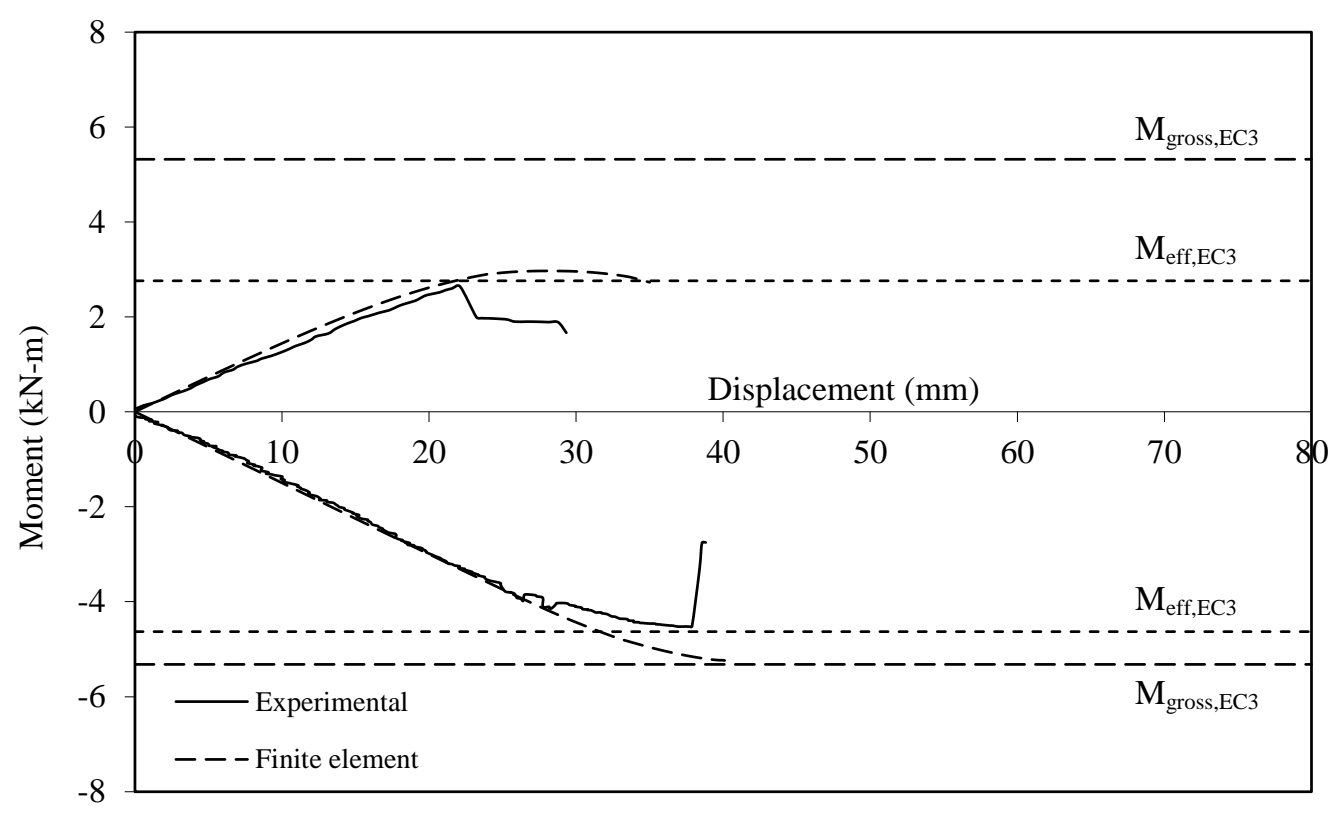

Figure 9: Variation of bending moment against central deflection for U-150-N3 and G-150-N2 specimens

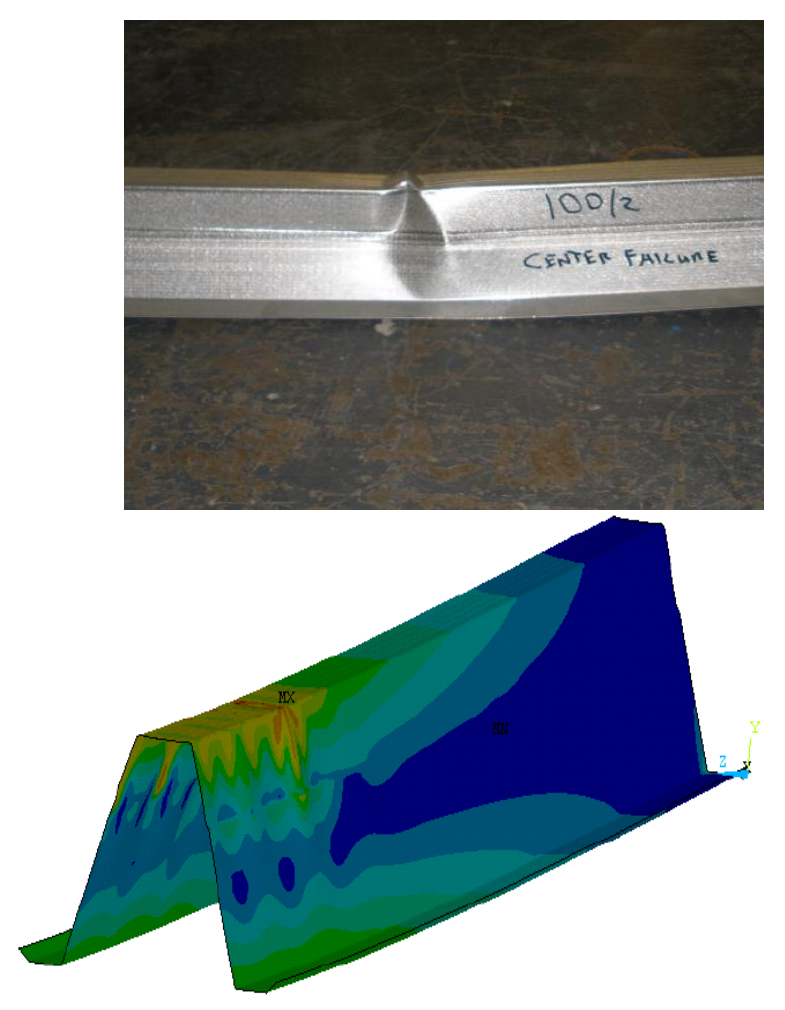

Figure 10: Comparison of deformed shape for downwards loading condition 

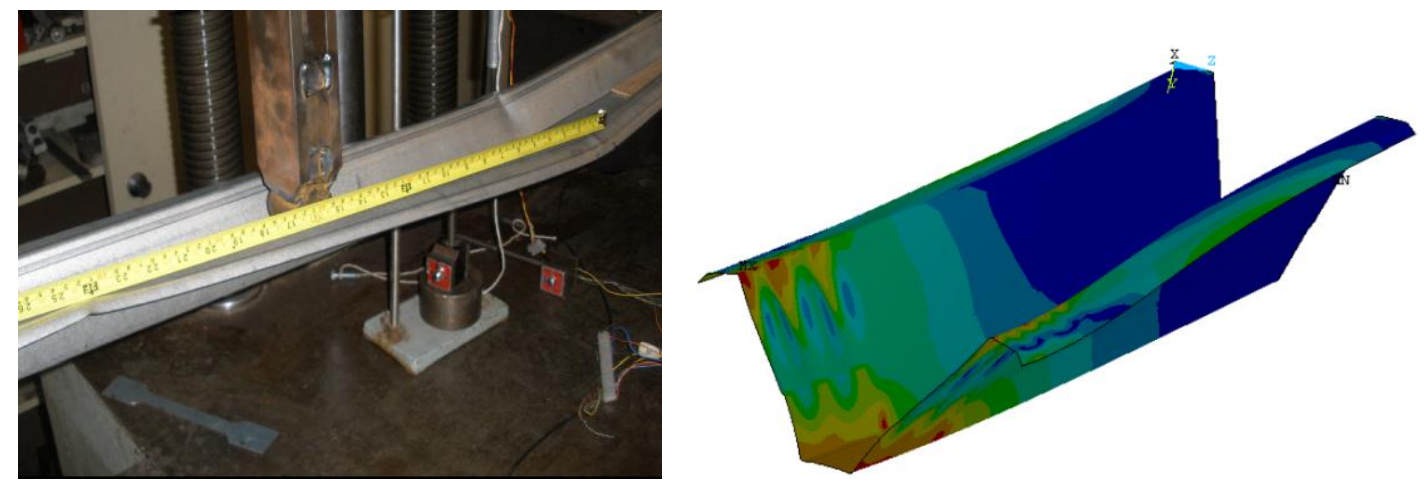

Figure 11: Comparison of deformed shape for upwards loading condition

\section{Conclusions}

An experimental investigation of a cold formed top-hat sections subjected to four point bending has been presented, in both the upwards and downwards loading direction. The results are compared against Eurocode 3 design calculations and finite element analysis.

In uplift loading, Eurocode was generally conservative. However, under gravity loading the Eurocod overestimated the strength of the top hat sections by $12 \%$.

The finite element model overestimated the strength of the top hat sections in uplift loading by approximately $15 \%$. This could be explained by the fact that geometrical imperfections were not modelled. Under gravity loading, the finite element model overestimated the strength by approximately $15 \%$ for the larger two sections, although for the smaller two sections a good agreement was achieved.

\section{Acknowledgement}

The Authors would like to acknowledge the Capital Steel Buildings for providing all test specimens. The experimental work was carried out by Angus Potter, as part of his undergraduate research project. The authors also wish to thank $\mathrm{Mr}$ Chris Cameron and Mr Andrew Crockett for their assistant in preparing the specimens and carrying out the experimental testing. 


\section{References}

[1] V.V. Acharya, R. M. Schuste, "Bending tests of hat sections with multiple longitudinal stiffeners", Fourteenth international specialty conference on coldformed steel structures, St. Louis, Missouri, 1998.

[2] M.M. Pastor, F. Roure, "Open cross-section beams under pure bending I. Experimental investigations", Thin-Walled Structures, Volume 46, Pages 476483, 2008.

[3] M.M. Pastor, F. Roure, "Open cross-section beams under pure bending II. Finite element simulation", Thin-Walled Structures, Volume 47, Pages 514521, 2009.

[4] D. Honfi, "Neural network based genetic algorithm optimization of hat-shaped beams", Proceedings of the Fifth International Conference on Engineering Computational Technology, Civil-Comp Press, Paper 52, Stirlingshire, 2006.

[5] A. Potter, "A comparison between physical testing results and numerical calculation methods pertaining to the determination of moment capacity and deflection", Final year project thesis, University of Strathclyde, Glasgow, 2010.

[6] BS EN 2001. 10002-1, "Tensile testing of metallic materials method of test at ambient temperature", British Standards Institution, 2001.

[7] BS EN 1993-1-3, Eurocode 3, "Design of Steel Structures; Part 1.3: Supplementary Rules for Cold Formed Thin Gauge Members and Sheeting", Brussels, Belgium, 1996.

[8] ANSYS “Release 11- User’s Manuals”, ANSYS Inc, 2011.

\section{Appendix-Notation}

\begin{tabular}{|l|l|}
\hline COV & Coefficient of variation; \\
\hline$E$ & Young's modulus of elasticity; \\
\hline FEA & Finite element analysis; \\
\hline $\mathrm{M}_{\mathrm{u}}^{\text {EXP }}$ & Experimental ultimate moment capacity; \\
\hline $\mathrm{M}_{\mathrm{u}}{ }^{\text {FEA }}$ & Ultimate moment capacity predicted from finite element analysis; \\
\hline $\mathrm{M}_{\mathrm{gross}, \mathrm{EC} 3}$ & Gross moment capacity predicted from Euro code-3; \\
\hline $\mathrm{M}_{\mathrm{eff}, \mathrm{EC} 3}$ & Effective moment capacity predicted from Euro code-3; \\
\hline$t$ & Thickness of section; \\
\hline$\sigma_{0.2}$ & Static $0.2 \%$ proof stress; and; \\
\hline$\sigma_{u}$ & Static ultimate tensile strength; \\
\hline
\end{tabular}

